\title{
Callus Induction of Leaves and Stems in Krisan (Chrysanthemum morifolium Ramat cv Dewi ratih) with Alternative Foliar Fertilizers Media
}

\author{
Ahmad Saifun Naser*, Muhammad Wisnu \\ Department of Biology, Faculty of Sciences and Technology, Universitas Islam Negeri Sunan Kalijaga Yogryakarta, \\ J1. Marsda Adisucipto, Yogyakarta, 55281, Indonesia. \\ Corresponding author* \\ saifun98@gmail.com
}

Manuscript received: 11 October, 2020. Revision accepted: 16 November, 2020. Published: 18 July, 2021.

\begin{abstract}
Availability of quality seeds in production of krisan (Chrysanthemum morifolium Ramat cv Dewi ratih) cultivation is still rare, therefore research on seed multiplication through tissue culture is needed. The media used in tissue culture is relatively expensive for home industry. This study aims to determine the respond of leaf and stem explants using foliar fertilizers (Growmore, Gandasil D and Mutiara) as an alternative media for callus inductions. This study used a Completely Randomized Design (CRD) consisted of 4 treatments: P0: $1 / 2$ MS + 0,25 mg/l BAP, P1 (Growmore + 0,25 mg/l BAP), P2 (Gandasil D + 0,25 mg/l BAP), P3 (Mutiara + 0,25 mg/l BAP). The variables observed in this study included callus appearance time, callus color and callus texture. The result of this study indicated that the use of BAP (6-Benzyl Amino Purine) affected the time of callus formation and callus morphology. Callus was formed on leaf explants 13 days after planting while on stem explants 7 days after planting and compact texture. Growmore $+0,25 \mathrm{mg} / \mathrm{l}$ BAP treatment yields the best callus on leaf explant, while Gandasil D + 0,25 mg/l BAP treatment yields the best callus on stem explant.
\end{abstract}

Keywords: BAP (6-Benzyl Amino Purine); krisan (Chrysanthemum morifolium Ramat cv Dewi ratih); plant tissue; alternative media (Growmore, Gandasil D and Mutiara).

\section{INTRODUCTION}

Chrysanthemum is an ornamental plant that has a high economic value due to the beauty of the flowers. According to Mustakim et al., (2015) the flowers of Chrysanthemum containing antioxidants that play a role in detoxifying toxins in the body and improve blood circulation. Chrysanthemum plants could be used as a raw material for antibiotic drugs and sharpens eye vision (Mani \& Senthil 2011; Lin \& Herly, 2010).

Chrysanthemum plant (Chrysanthemum morifolium Ramat cv Dewi ratih) is cultivated in almost all of Indonesia. The dominating area includes East Java, Central Java, West Java, South Sulawesi and North Sumatra (Badan Pusat Statistik dan Direktorat Jendral Holtikultura, 2017). C. morifolium plants contained secondary metabolite of flavonoid and volatile compounds. The examples of the compound are quercetin-3-galactoside, luteolin 7-glucoside, quercitrin, myricetin, luteolin, apigenin, and kaempferol (Sun et al., 2010).

The successful morphogenesis from cultivated plants determined by the explants. According Vidyasagar, (2006) explant is part of the plant that is used as a material for the initiation of culture. Explant can be cells (cell culture), protoplast (protoplast culture), medulla (tissue culture), apical meristem or lateral (shoot culture) and cut stems or leaves (organ culture) (Dwiyani, 2015). The juvenile physiological explants are better for the tissue culture then the old one. The part of juvenile plants have higher regenerations than the mature one (Gunawan, 1987).

Callus is an unorganized and actively dividing tissue that usually produced by injured plants in tissue culture. According to Dwiyani, (2015) callus can be obtained by tissue roots, leaves and stems in the plant that occurred through the process of indirect embryogenesis. Explant derived from meristematic tissue developed faster than tissue of thin-walled cells that containing lignin (Nugroho \& Sugito, 2001). Plant growth regulators (PGR) could be used for additional plant tissue cultured media. According from Gunawan (1987) PGR usage affected growth and morphogenesis in cell, tissue and organ culture caused by the interaction between media determined culture development.

Media are very important in tissue culture methods, even the success of the tissue culture is determined by the media used (Gunawan, 1987). The essential elements in the media included inorganic salts, vitamins, energy source and carbon. The essential nutrients are nutrients 
that used by plant to completed their life cycle. The functions of these nutrients cannot be replaced by other elements. It is required by the plants in the metabolic process as inorganics components or cofactors in enzyme reactions (Orcutt \& Nilsen, 2000).

Foliar fertilizers like Mutiara and Growmore can be alternative substitution for micronutrient and macronutrient MS (Murashage and Skhoog) media (Shintiavira et al., 2012). Gandasil D and Growmore are compound fertilizers that contain complete macronutrient and micronutrient. Sometimes the alternative media usage added by some nutrient like casein hydrolysate $(\mathrm{CH})$, corn oil, coconut water and tomato juice. Widiastoety \& Purbadi (2003) stated that $150 \mathrm{ml} / \mathrm{L}$ usage of coconut water that pour into the media could have an effect for increased growth, height, length and width leaves and the number of roots to Dendrobium orchid plantlet.

This study aims to determine the response of leaf and stem explants to use foliar fertilizers (Growmore, Gandasil D \& Mutiara) with added Plant growth regulators (PGR) as an alternative media for callus inductions of Chrysanthemum morifolium Ramat cv Dewi ratih. It is hoped that this research can be used as material for consideration of a substitute for MS (Murashige and skoog) which is relatively expensive for home-scale tissue culture farmers given the nutrient content in foliar fertilizers meet the needs for optimal plant growth and development.

\section{METHODS}

This research was conducted from $15^{\text {th }}$ February to $20^{\text {th }}$ September 2019 at the Embryology Laboratory of UIN Sunan Kalijaga Yogyakarta.

\section{Materials}

The plant parts used as explants in this study were the leaves and stems of Chrysanthemum morifolium Ramat cv Dewi ratih. The growth media used in this study were $1 / 2$ MS medium (Murasahge and skoog) and compound fertilizer Gandasil D, Growmore and Mutiara. Furthermore, the chemicals used were agar, BAP powder, $1 \mathrm{M} \mathrm{HCl}$ solution, distilled water, $70 \%$ alcohol, sterile tissue paper, sterile aluminium foil, filter paper and plastic cling wrap.

\section{Procedure}

\section{Sterilization of ingredients}

The explants that had been prepared for sterilization were put in a tea filter, then washed with running water for 5 minutes. Remove the explants and soak them in a $10 \%$ alcohol solution for 3 minutes while shaking them manually then rinsing with distilled water 3 times (1-3 minutes), then the explants were removed and immersed in $5 \%$ chloroc $(\mathrm{NaOcl})$ solution while shaking it manually for 35 minutes then $10 \%$ chlorine for 3-5 minutes. Then rinse with distilled water 3 times (1-3 times). The explants were then let dry in Erlenmeyer and covered with sterile tissue in an inverted position.

\section{Preparation of hormone solution}

$100 \mathrm{mg}$ of BAP powder was dissolved in $2.5 \mathrm{ml}$ of $1 \mathrm{~N}$ $\mathrm{HCl}$ solution. The material was heated and stirred until dissolved. Then, add distilled water slowly until the volume of the solution reaches $100 \mathrm{ml}$. Furthermore, the $\mathrm{PH}$ of the solution is adjusted to 5.0. The solution was transferred to the stock container and labelled. $1000 \mathrm{ppm}$ BAP stock solution $(1 \mathrm{ppm}=1 \mathrm{mg} / \mathrm{l})$ were stored in a refrigerator.

\section{Media}

Media MS (Murashige and skoog)

2.215 grams of instant $1 / 2$ MS medium diluted in $1000 \mathrm{ml}$ of distilled water. Then added the hormone $0.25 \mathrm{mg} / \mathrm{l}$ BAP. The $\mathrm{pH}$ measurement of the solution was carried out in the range of 5.6 - 5.9. After that, 8 grams of agar powder and 30 grams of sugar are added to the mixture of media and hormones. Making $1 / 2$ MS resulted in a positive control, namely media $1 / 2 \mathrm{MS}+0.25 \mathrm{mg} / \mathrm{l} \mathrm{BAP}$, each consisting of 10 replications.

$1 / 2$ MS solution was heated to a boil, stirring chili sauce until the powder was completely dissolved. After boiling, $1 / 2$ MS liquid medium was poured into the culture bottle and closed tightly with aluminium foil. The culture bottles that have been filled with the media were then put into an autoclave to be sterilized at a pressure of $17 \mathrm{psi}$ at $121^{\circ} \mathrm{C}$ for 15 minutes. Finally, the culture bottles were stored in the culture room at $12^{\circ} \mathrm{C}$. After one to two days, the culture bottles are examined for clots or for contamination.

\section{4. explant inoculation and culture incubation}

Explant was obtained from the leaves of the chrysanthemum. Each culture bottle was planted with three leaf explants with a size of $0.5 \mathrm{~cm} \mathrm{X} 0.5 \mathrm{~cm}$. Each explant was planted 10 times in a variety of different growth media according to Table 1 . The culture bottles that have been planted with explants were then stored in the culture room at a temperature of $16^{\circ} \mathrm{C}$.

Table 1. Design of research treatment Chrysanthemum morifolium Ramat cv Dewi ratih.

\begin{tabular}{l}
\hline Treatment \\
\hline A. Positive control (p0: 1/2 MS +0,25 mg/l BAP) \\
B. Alternative media (P1: Growmore + 0,25 mg/l BAP) \\
C. Alternative media (P2: Gandasil D + 0,25 mg/l BAP) \\
D. Alternative media (P3: Mutiara + 0,25 mg/l BAP) \\
\hline
\end{tabular}

\section{Observation of parameters}

Observations were made for once every two days after the Day After Planting (DAP). Until callus formed on all 
explants. The parameters observed during the study are as follows:

- Callus morphology and color

The morphology observed included crumb and compact callus texture and a white, green or brown callus color

- Callus appearance time

The time of callus formation was determined by observing the explants from the beginning of planting until the first callus appeared.

\section{RESULTS AND DISCUSSION}

Leaf and stem explants on Chrysanthemum morifolium Ramat cv Dewi ratih are able to form callus. Callus formation on leaf and stem explants had different times. On the stem, callus formed 7 DAP (Days After Planting) while on callus leaves formed 13 DAP (Days After Planting). It can be seen in tables 2 and 3 . The callus formed in all treatments was compact type. The compact callus texture in this study was caused by the provision of cytokinins, as the statement by Purwaningsih et al., (2016) that compact callus has the effect of giving cytokines to the media that play a role as nutrient transfer.

Table 2. Callus texture and color, as well as other descriptions of leaf explants (C. morifolium Ramat cv. Dewi ratih).

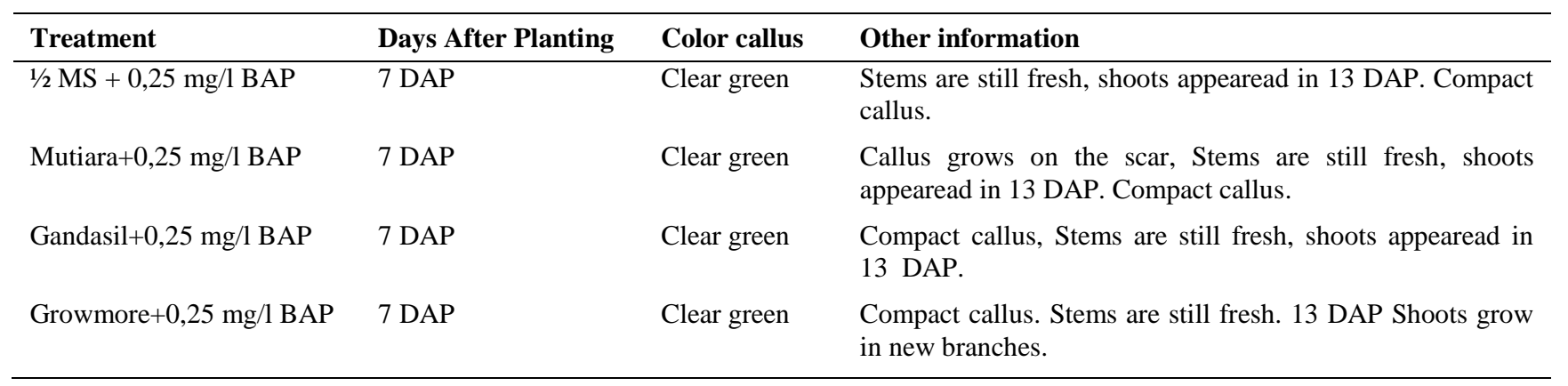

Table 3. Callus texture and color, as well as other descriptions of stems explants (C. morifolium Ramat cv. Dewi ratih).

\begin{tabular}{|c|c|c|c|c|}
\hline Treatment & $\begin{array}{l}\text { Days After } \\
\text { Planting }\end{array}$ & $\begin{array}{l}\text { Callus } \\
\text { texture }\end{array}$ & Other information & Color callus \\
\hline $1 / 2 \mathrm{MS}+0,25 \mathrm{mg} / \mathrm{l} \mathrm{BAP}(+)$ control & 13 DAP & compact & $\begin{array}{l}\text { The leaves are swollen, the scars form a clear } \\
\text { white callus. }\end{array}$ & Clear green callus \\
\hline Mutiara + 0,25 mg/l BAP (-) & 13 DAP & compact & $\begin{array}{l}\text { There is browning on the scar, getting thicker, } \\
\text { on the scar forming a clear white callus. }\end{array}$ & Clear green callus \\
\hline Gandasil + 0,25 mg/l BAP (-) & 13 DAP & compact & $\begin{array}{l}\text { The leaves are swollen, browning on the } \\
\text { wound, forming a clear callus on the wound. }\end{array}$ & Clear green callus \\
\hline Growmore + 0,25 mg/l BAP & 13 DAP & compact & $\begin{array}{l}\text { The leaves are swollen, callus is found all } \\
\text { over the leaves. }\end{array}$ & Clear green callus \\
\hline
\end{tabular}

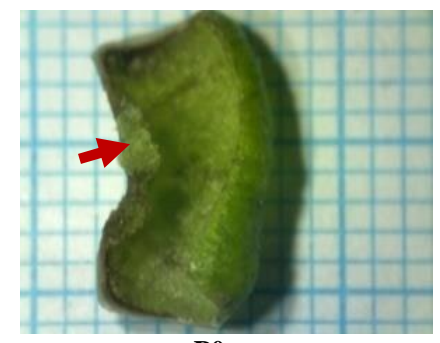

P0

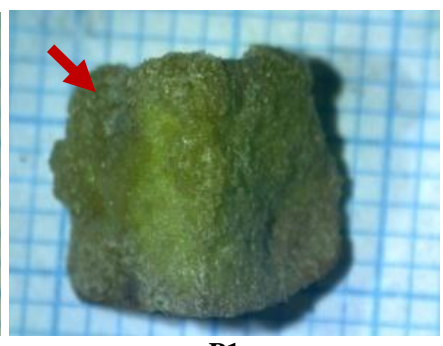

P1

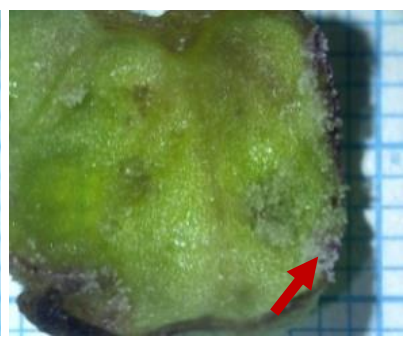

P2

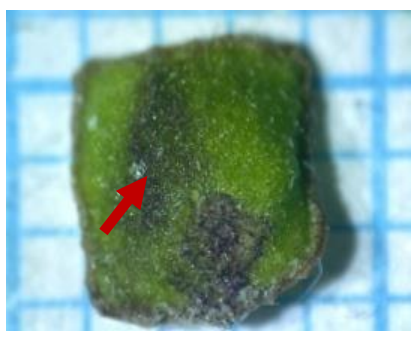

P3

Figure 1. Callus on leaves explants with the treatment P0, P1, P2, and P3.

Callus)

In the formation before, callus was followed by swelling of the explants. This is in accordance with the statement of Hariyanti et al., (2016) stating that callus is formed followed by a whitish or clear swelling around the scar which eventually covers the entire surface of the explants. Callus on the leaf (Table 3) is formed marked 
by the swelling of explant tissue on 13 DAP, then followed by the formation of clear grains on scar and the uneven explant surface. Callus formed in each treatment leaf explants could be seen in Figure 1.

The callus that formed on the stem (Table 2) is at tip and base of the stem because that part is a place of scar on leaves. On the stem explants also formed shoot on 13 DAP (Table 2). Callus and shoots formed on stem explants can be seen in Figure 2.
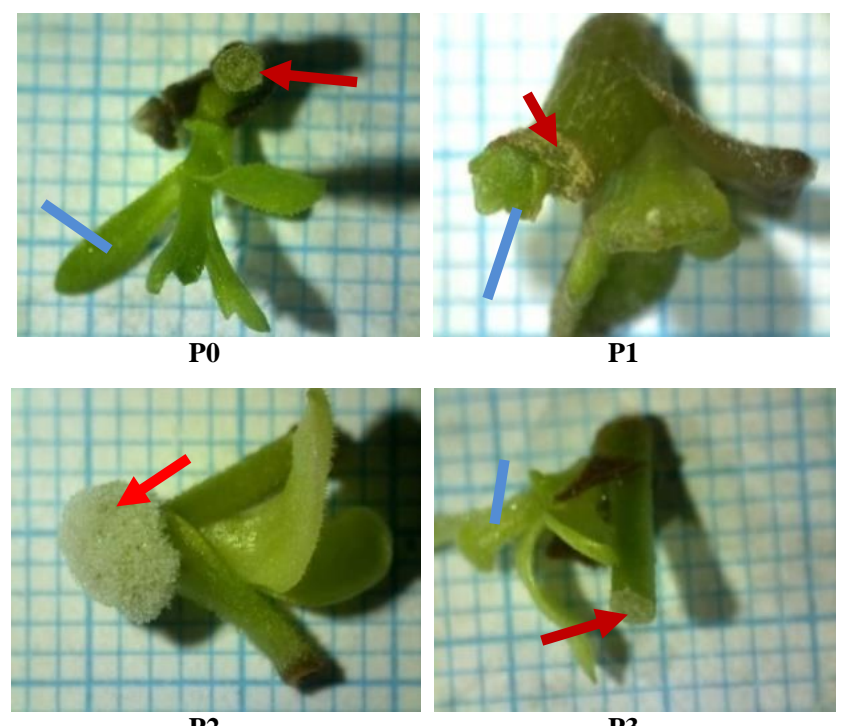

P2

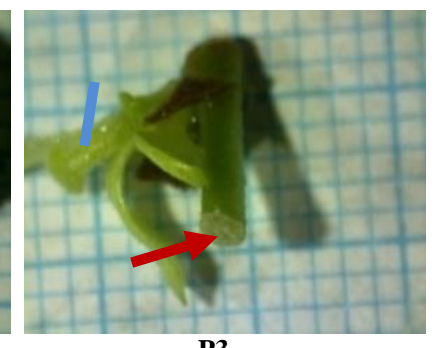

- : Soots, $\rightarrow$ : Callus

Figure 2. Callus on stem explants with the treatment P0, P1, P2 and P3.

\section{Leaves}

Treatment of P1 (Figure 1) showed that Growmore + $0,25 \mathrm{mg} / \mathrm{l} \mathrm{BAP}$ foliar fertilizers able to become an alternative medium for callus induction, because Growmore fertilizer contained sufficient nutrient. Callus was formed on 13 DAP which is compact texture, fresh green in the entire leaves surfaced and accompanied by swelling explants. The formation of callus is a sign that the explants are competent. According Lubis (2016) Chrysanthemum morifolium Ramat cv merahayani which is cultured by Growmore media $2 \mathrm{~g} / \mathrm{l}$ did not significant with $1 / 2$ MS media in media $1 / 2$ MS in variable shoot height, shoot weight and number of roots.

Treatment P0 (1/2 MS $+0,25 \mathrm{mg} / \mathrm{l}$ BAP) in leaves explants could be callus inductions. Callus was formed at 13 DAP by initiating the formation of white grains then growing / forming calluses on the scar. (Figure 1: $\mathrm{P} 0)$. This is different from the Growmore treatment where callus grows evenly over the surface of the leaf explants. The color of callus $1 / 2$ MS is clear green and compact texture. Callus color can be used as an indicator of the quality of the callus. Callus which is green in color has good quality because it still contains chlorophyll (Siregar et al., 2013). There was browning in the $1 / 2$ MS (P0) explant (Figure 1) which was caused by the presence of phenolic compounds which were derived from the role of the polyphenoloxidase enzyme. Phenolic compounds are derived from plant secondary metabolites stored in vacuoles. When the explant is sliced, the vacuole breaks, the phenol compound is oxidized and then the compound is oxidized. This will cause the explants to turn brown. When phenol compounds are oxidized on the media, the media must be replaced. If not replaced it will lead to explant poisoning and death. (Dwiyani, 2015).

The treatment P2 (Gandasil D $+0.25 \mathrm{mg} / \mathrm{l} \mathrm{BAP}$ ) showed that the explants were able to form callus. The callus formed 13 DPA which compact texture, clear green color that is on the scar and surface of the explant (table.2). The callus that grows on the scar has a grainy texture so that the scar turns white. There is a little browning on scar in leaf explant indicated when cutting, However, the part that experienced browning could still induced callus on the surface of leaf explants (Figure 1). The treatment P2 (Gandasil $+0.25 \mathrm{mg} / \mathrm{l} \mathrm{BAP}$ ) indicated that it could be used as an alternative medium for homescale tissue culture. Nutrient that contained in foliar fertilizer Gandasil D have contained sufficient nutrient for callus induction. Matatula (2003) The addition of coconut water to Gandasil D media caused an increase in plant height, number of leaves, number of roots, shoot wet weight and root wet weight in vitro. Before the callus formed, leaf explants have some symptoms. On 3 DAP the surface of the leaf explants began to become uneven and stretched up to 9 DAP then on 13 DAP leaf explant begin formed callus until 22 DPA. callus began to appear clearly almost all over the leaf surface.

Callus on the treatment P3 (Mutiara $+0,25 \mathrm{mg} / \mathrm{l}$ BAP) was compact in the texture and clear green color that grow up in the scar and surface leaf explant. P3 leaf explants on 3 DAP have responded to the treatment of the media used This causes the leaf surface to be uneven and there are spots. this condition is stilled same until on 7 DAP. The P3 leaf explants before forming the callus were stretched This is due to the role of the hormone cytokinins then in the scar begun to form clear white grains and spread on the leaf surface. some of the P3 leaf explants experienced browning at 9 DAP. However, the explants are stilled able to form callus. Callus begun to grow on leaf explants after 13 DAP. Leaf explants treated P3 can be classified as competent because they are able to form callus in response to the media. P3 treatment explant media (Mutiara $+0,25 \mathrm{mg} / \mathrm{l} \mathrm{BAP}$ ) can be used as an alternative media.

Treatment of the three leaf explants (Figure 1) showed that foliar fertilizer has the potential as a alternative medium to replace $1 / 2$ MS. The treatment of P1 leaf explant (Growmore $+0,25 \mathrm{mg} / \mathrm{l} \mathrm{BAP}$ ) yielded the best callus then the others treatment. Because callus on the P1 leaf explant has a fresh green color and grow entire the surface leaf explant (on surface and inside). 


\section{Stem}

The callus was formed from stem explant that showed the equal result (Table.2). Callus on the treatment $1 / 2 \mathrm{MS}$, Growmore, Gandasil D and Mutiara appeared on 7 DAP. The four treatments indicated that there is potential of the media in growing callus on stem explants. Stem explants which formed callus indicated that organogenesis had occur. The formation of callus on stem explants is due to the presence of endogenous auxin hormones that initiated in the scar. Callus is formed at the tip and base of the stem in the explant because that position has been injured (Figure 2).

shoots appeared on the nodes in all treatments stem explants ( $1 / 2$ MS, Growmore, Mutiara and Gandasil D) after 13 DAP until 22 DAP. Shoot formation occurs due to the role of the hormone cytokinin (BAP). According Dwiyani (2015). if want to form callus on the explants, the explants are planted in callus inducing media like medium + auxin. However, if want to shoot inducing, the explant planted in shoot inducted, like medium + sitokinin (BAP). Its can be inferred that the stem explant has cytokinin hormone higher than auksin.

Stem explant in P1 treatment (Growmore $+0,25$ $\mathrm{mg} / \mathrm{L} \mathrm{BAP}$ ) (Figure 2) formed callus at stem tips scar. The texture callus is compacted and clear green color that appear on 7 DAP. Callus was formed due to endogenous auxin hormone in stem. Shoots grow on the nodes stem after 13 DAP in scar. The P1 treatment stem explants were swollen due to the effects of the cytokinin hormone. New leaves grow on shoots after 15 DAP and the callus is getting bigger.

P2 treatment stem explants (Gandasil D + $0.25 \mathrm{mg} / \mathrm{l}$ BAP) (Figure 2) were able to form callus and shoots. Browning appear on P2 treatment started 3 DAP, Although browning, callus can still be induced on the cutting marks. Callus was formed at the base of stem while shots are formed in nodus. In 7 DAP, callus can be seen with clearly, compact texture and clear green color. Meanwhile, shoots can be seen clearly on 13 DAS. Stem explants in P2 treatment (Gandasil D + 0,25 mg/l BAP) get the best callus than the others treatment. Two young leaves clearly appear on the shoot after 15 DAP. Callus and shoot have pale green color and getting a bigger until 17 DPA. The color of callus turns white and shoot color getting green on $20 \mathrm{DPA}$.

In P0 treatment ( $1 / 2 \mathrm{MS}+0,25 \mathrm{mg} / \mathrm{l} \mathrm{BAP})$ (Figure 2), callus appeared on 7 DPA on the cut marked at stem tips. On 9 DPA, browning and callus could be seen clearly. Two leaves appear on the shoot at nodus stem on 13 DPA. After that the new leave appeared in shoots on 15 DPA. The stem of P0 treatment explant still looked fresh. the leaves on the shoot begun to enlarge and the callus can still be seen clearly on 20 DPA.

Browning appeared in the P3 (Mutiara+ 0,25 mg/l BAP) treatment stem explant getting on 3 DPA. On 6 DPA the stem explant is still green fresh and the callus appeared in stem explant started on 7 DPA at cutting marked stem tips. The callus was compact in texture and had a clear white color, but the callus formed was not as much as in the P0 stem explant treatment. Callus was seen more clearly at 9 DAP and 2 new leaves appeared on shoots located on the nodus stem on 13 DAP. On 15 DAP there are addition two new leaves again on the stem. On 17 DPA there are new leaves again on the explant stem shoots. The shoots are still developed and the color of stem still fresh green until 20-22 DPA. The stem of P3 treatment has a characteristic that the shoot bigger than P0 treatment. But The number of leaves formed on the stem explants in treatment P3 was less than in treatment $\mathrm{P} 0$.

\section{CONCLUSION}

The foliar fertilizer were able to induce callus in the Chrysanthemum morifolium Ramat cv Dewi ratih in vitro, the P1 treatment (Growmore) yielded the best callus in the leaf explants and the P2 treatment (Gandasil D) yielded the best callus in the stem explants.

Conflict of interest: The author declares that there are no conflicts of interest concerning the publication of this article.

\section{REFERENCES}

Badan Pusat Statistik dan Direktorat Jendral Holtikultura (2017) Luas Panen, Produksi dan Produktivitas Tanaman Krisan, 2016-2017.

Dwiyani, R (2015) Kultur Jaringan Tanaman, Pelawa Sari Percetakan \& Penerbit., Bali.

Gunawan, L.W (1987) Teknik Kultur Jaringan Tumbuhan. PAU Bioteknologi IPB. Bogor.

Hariyati, M., I. Bachtiar, \& P. Sedijani (2016) Induksi kalus tanaman krisan (Chrysanthemum morifolium) dengan pemberian benzil amino purin (BAP) dan Dichlorofenoksi acetil acid (2,4-D). Jurnal Penelitian Pendidikan IPA 2 (1).

Lubis, YM (2016) 'Regenerasi in vitro tanaman krisan (Chrysanthemum morifolium) melalui tunas aksiler sebagai respon terhadap media dasar dan benzyl adenin serta aklimatisas plantlet', Skripsi, Fakultas Pertanian, Universitas Lampung, Bandar Lampung, hlm. 66.

Mani, T., Senthil, K (2011) Multiplication of Chrysanthemum through somatic embryogenesis. Asian Journal Pharma Technology 1 (1): 13-16

Matatula, A.J (2003) Substitution of MS medium with coconut nater and Gandasil D on chrysanthemum tissue culture. Eugenia 9 (4): 203-211.

Nugroho, A. \& Sugito, H (2001) Pedoman Pelaksanaan Teknik Kultur Jaringan Tanaman. Jakarta: PT Penebar Swadaya

Orcutt, D. M. \& E.T. Nilsen (2000) Physiology of Plants Under Stress. Soil and of Comercial Laboratoryes. Easter Press. England.

Purwaningsih, W., S. Febri, \& Kusdianti (2016) Formation flavonoid secondarymetabolites in callus culture of Chrysanthemum cinerariefolium asalternatif provision medicine Proceedings of International Seminaron 
Mathematics, Science, and Computer Science Education (MSCEIS2015).

Shintiavira, H., Soedarjo, M., Suryawati, S., \& Winarto, B. (2012). Studi Pengaruh Substitusi Hara Makro dan Mikro Media MS dengan Pupuk Majemuk dalam Kultur In Vitro Krisan. Jurnal Hortikultura, 22(4), 334-341. doi: http://dx.doi.org/10.21082/jhort.v22n4.2012.p334-341

Siregar, L.H., Siregar L.A.M., Putri, L. P (2013) Pengaruh $\alpha-$ benzil aminopurin dan $\alpha$ - asam asetat naftalena terhadap pertumbuhan akar Boesenbergia flava secara in vitro. Jurnal Agroekoteknologi 1 (3): 511-522.
Sun, Q.L., S. Hua, S., Ye, J.H., Zheng, X.Q., \& Liang, Y.R (2010) Flavonoids and volatiles in Chrysanthemum morifolium Ramat flower from Tongxiang County in China. African Journal of Biotechnology 9(25):3817-3821

Vidyasagar, K (2006) National Conference on Plant Biotechnology. China.

Widiastoety, D., \& -, P. (2003). Pengaruh Bubur Ubikayu dan Ubijalar terhadap Pertumbuhan Plantlet Anggrek Dendrobium. Jurnal Hortikultura, 13(1), 1-6. doi: http://dx.doi.org/10.21082/jhort.v13n1.2003.p1-6. 
Table S1. Observation of daily development on leaf explants.

\begin{tabular}{|c|c|c|c|c|}
\hline Date & MS & Mutiara & Gandasil D & Growmore \\
\hline $\begin{array}{l}26-07-2019 \\
3 \text { DPA }\end{array}$ & $\begin{array}{l}\text { Uneven surface, there are } \\
\text { spots }\end{array}$ & $\begin{array}{l}\text { Uneven surface, there are } \\
\text { spots }\end{array}$ & $\begin{array}{l}\text { Starting to warp, uneven } \\
\text { surface. }\end{array}$ & $\begin{array}{l}\text { Some look flat, uneven } \\
\text { surface. }\end{array}$ \\
\hline $\begin{array}{l}\text { 29-07-2019 } \\
6 \text { DPA }\end{array}$ & Still same the day before & Still same the day before & Still same the day before & $\begin{array}{l}\text { Many are curved, uneven } \\
\text { surface }\end{array}$ \\
\hline $\begin{array}{l}30-07-2019 \\
7 \text { DPA }\end{array}$ & Still same the day before & Still same the day before & Still same the day before & Still same the day before \\
\hline $\begin{array}{l}1-08-2019 \\
9 \text { DPA }\end{array}$ & More uneven surface & $\begin{array}{l}\text { More uneven surface, } \\
\text { browning in edge }\end{array}$ & Still fresh, uneven surface & Uneven surface, still fresh \\
\hline $\begin{array}{l}5-08-2019 \\
13 \text { DPA }\end{array}$ & $\begin{array}{l}\text { Enlarged leaves and callus } \\
\text { appeared }\end{array}$ & $\begin{array}{l}\text { There are already } 9 \\
\text { explants with callus }\end{array}$ & $\begin{array}{l}\text { Appeared callus in } \\
\text { 1explant dan } 1 \text { browning }\end{array}$ & $\begin{array}{l}\text { Enlarged leave and callus } \\
\text { appeared }\end{array}$ \\
\hline $\begin{array}{l}7-08-2019 \\
15 \text { DPA }\end{array}$ & $\begin{array}{l}\text { Browning appeared, } 1 \\
\text { explant enlarged }\end{array}$ & $\begin{array}{l}\text { Callus visible more } \\
\text { clearly and enlarged }\end{array}$ & $\begin{array}{l}\text { Callus visible more clearly } \\
\text { and } \\
\text { leaf enlarged }\end{array}$ & $\begin{array}{l}\text { Callus visible more } \\
\text { clearly at cutting marks } \\
\text { and surface }\end{array}$ \\
\hline $\begin{array}{l}9-08-2019 \\
17 \text { DPA }\end{array}$ & Still same the day before & The part of leaf browning & $\begin{array}{l}\text { Callus visible more } \\
\text { clearly }\end{array}$ & $\begin{array}{l}\text { increased callus and } \\
\text { clearly, explant enlarged }\end{array}$ \\
\hline $\begin{array}{l}12-08-2019 \\
20 \text { DPA }\end{array}$ & $\begin{array}{l}\text { Some of the leaves have } \\
\text { blackened and enlarged }\end{array}$ & $\begin{array}{l}\text { Leaf still fresh, Callus } \\
\text { visible }\end{array}$ & 1 explant browning & $\begin{array}{l}\text { increased callus and } \\
\text { exsplan enlarged }\end{array}$ \\
\hline $\begin{array}{l}14-08-2019 \\
22 \text { DPA }\end{array}$ & $\begin{array}{l}\text { There were explants that } \\
\text { just appeared callus }\end{array}$ & $\begin{array}{l}\text { Leaf still fresh, Callus } \\
\text { visible }\end{array}$ & $\begin{array}{l}\text { Callus is visible on almost } \\
\text { all surfaces }\end{array}$ & $\begin{array}{l}3 \text { explants browning and } 1 \\
\text { explant appeared callus }\end{array}$ \\
\hline
\end{tabular}

Table S2. Observations of the daily development of observations on the stem.

\begin{tabular}{|c|c|c|c|c|}
\hline Date & MS & Mutiara & Gandasil D & Growmore \\
\hline $\begin{array}{l}26-07-2019 \\
3 \text { DPA }\end{array}$ & $\begin{array}{l}\text { Still green fresh, browning } \\
\text { at cutting edges. }\end{array}$ & $\begin{array}{l}\text { Still green fresh, browning } \\
\text { at cutting edges. }\end{array}$ & $\begin{array}{l}\text { Still green fresh, browning } \\
\text { at cutting edges }\end{array}$ & $\begin{array}{l}\text { Still green fresh browning } \\
\text { at cutting edges }\end{array}$ \\
\hline $\begin{array}{l}29-07-2019 \\
6 \text { DPA }\end{array}$ & $\begin{array}{l}\text { Still green fresh, browning } \\
\text { at cutting edges. }\end{array}$ & $\begin{array}{l}\text { Still green fresh, there is } \\
\text { browning at the base of } \\
\text { the cut }\end{array}$ & $\begin{array}{l}\text { Still green fresh, browning } \\
\text { at cutting edges }\end{array}$ & $\begin{array}{l}\text { Still green fresh, some of } \\
\text { explant browning at } \\
\text { cutting edges }\end{array}$ \\
\hline $\begin{array}{l}\text { 30-07-2019 } \\
7 \text { DPA }\end{array}$ & $\begin{array}{l}\text { Callus appeared at cutting } \\
\text { marks }\end{array}$ & $\begin{array}{l}\text { base brown, callus appears } \\
\text { but not as much as MS }\end{array}$ & $\begin{array}{l}\text { Callus appears but not as } \\
\text { much as MS }\end{array}$ & Callus appeared. \\
\hline $\begin{array}{l}1-08-2019 \\
9 \text { DPA }\end{array}$ & $\begin{array}{l}\text { The callus on the cut mark } \\
\text { was clearly visible, } \\
\text { browning is starting to } \\
\text { clear }\end{array}$ & $\begin{array}{l}\text { Callus is starting to clear, } \\
\text { some explant browning }\end{array}$ & $\begin{array}{l}\text { Callus clearly, the stem } \\
\text { begins to swell at the } \\
\text { bottom (elongation) }\end{array}$ & $\begin{array}{l}\text { Callus is starting to } \\
\text { clearer, the stem begins to } \\
\text { swell }\end{array}$ \\
\hline $\begin{array}{l}\text { 5-08-2019 } \\
13 \text { DPA }\end{array}$ & $\begin{array}{l}\text { Shoots are visible, there } \\
\text { are } 2 \text { new leaves on } \\
\text { nodus, new shoots }\end{array}$ & $\begin{array}{l}\text { Shoots are visible, callus } \\
\text { is still visible on the cut } \\
\text { marks. }\end{array}$ & $\begin{array}{l}\text { Callus still fresh, cut mark } \\
\text { browning, new shoots at } \\
\text { nodus. }\end{array}$ & $\begin{array}{l}\text { New shoots at nodus. } \\
\text { Callus still fresh. }\end{array}$ \\
\hline $\begin{array}{l}\text { 7-08-2019 } \\
15 \text { DPA }\end{array}$ & $\begin{array}{l}3 \text { shoods appeared in } \\
\text { nodus }\end{array}$ & $\begin{array}{l}3 \text { new leaves, the leaves } \\
\text { are longer and clearer }\end{array}$ & $\begin{array}{l}\text { Looks new shoots tips, } 2 \\
\text { new leaves }\end{array}$ & $\begin{array}{l}\text { The callus is getting } \\
\text { bigger, young leaves } \\
\text { grow, there are no new } \\
\text { leaves yet }\end{array}$ \\
\hline $\begin{array}{l}\text { 9-08-2019 } \\
17 \text { DPA }\end{array}$ & $\begin{array}{l}\text { New shoots and new } \\
\text { leaves grow in the nodus }\end{array}$ & $\begin{array}{l}\text { Shoots tips still fresh, } \\
\text { small leaves become large } \\
\text { and there are new leaf } \\
\text { candidates }\end{array}$ & $\begin{array}{l}\text { The callus is getting } \\
\text { bigger, there is new leaf, } \\
\text { then another candidate for } \\
\text { leaves appears again, } \\
\text { green clear color }\end{array}$ & New leaf, callus still fresh \\
\hline $\begin{array}{l}\text { 12-08-2019 } \\
20 \text { DPA }\end{array}$ & $\begin{array}{l}\text { The stems are growing } \\
\text { and still fresh, leaves start } \\
\text { bigger, callus is still } \\
\text { clearly visible }\end{array}$ & $\begin{array}{l}\text { New shoots develop on } \\
\text { the nodes }\end{array}$ & $\begin{array}{l}\text { The callus is getting } \\
\text { whiter, the leaves are } \\
\text { getting green clearly }\end{array}$ & Still same \\
\hline $\begin{array}{l}\text { 14-08-2019 } \\
22 \text { DPA }\end{array}$ & $\begin{array}{l}\text { Still bigger explant and } \\
\text { shoots are still small. }\end{array}$ & $\begin{array}{l}\text { Green shoots color, looks } \\
\text { bigger than } 1 / 2 \mathrm{~ms} \text { but } \\
\text { leaves less }\end{array}$ & $\begin{array}{l}\text { Leaf green clearly, leaves } \\
\text { a little but big. }\end{array}$ & $\begin{array}{l}\text { There are some that } \\
\text { haven't appeared yet. dark } \\
\text { green shoot color }\end{array}$ \\
\hline
\end{tabular}


THIS PAGE INTENTIONALLY LEFT BLANK 